Si en algunos casos su información fué deficiente -y aun llegó a cambiar el nombre de pila de un escritor para nosotros tan conocido como José Joaquín Fernández de Lizardi, a quien él llamó Manuel一, eso se subsana, en la reedición presente, con las oportunas notas de Andrés Henestrosa, complementarias, en lo biográfico y en lo bibliográfico.

El mismo Henestrosa, quien cuidó de la reedición, en las páginas que proceden a ésta y bajo el título de "José Zorrilla en México", traza con agilidad y finura la trayectoria del poeta español, a quien generosamente perdona — como lo han hecho ya los mexicanos- su ingratitud que le hizo adoptar posturas lamentables, porque prefiere recordar los aspectos constructivos de la obra de Zorrilla, en tal etapa de su existencia.

\title{
Francisco Monterde.
}

Octavio Paz, Libertad bajo palabra.-Tezontle. México, 1949.

Si se acepta la teoría aplicada en el análisis de más de una obra literaria, tal vez con mayor plausibilidad en el de la obra del joven Goethe, de que el genio permite al artista sublimación y liberación de su experiencia vivida, en la obra de arte, la palabra poética es el mágico don de Octavio Paz para poder aceptar, soportar y reconciliarse con el mundo en el cual por fuerza mayor el ser humano se encuentra en su limitación y con el cual cada uno tiene que desembrollarse. Lo dice así el poeta en la introducción de Libertad bajo palabra: "Contra el silencio y el bullicio invento la palabra." Estos elementos del mundo circundante, completa indiferencia, o apartamiento, $u$ hostilidad en el ambiente humano sin ser considerados como causas de prcocupaciones o angustias por el hombre ordinario, son para el individuo de aguda sensibilidad, i. e. para el poeta, lo que oprime y aisla. Dice el poeta en "El desconocido":

$$
\begin{aligned}
& \text { "E1 marcha solo, infatigable, eterno } \\
& \text { encarcelado en su infinito, } \\
& \text { como un solitario pensamiento, } \\
& \text { como un fantasma que buscara un cuerpo." }
\end{aligned}
$$

En los varios grupos de poemas que, según una cronología más bien general que estrictamente metódica, pertenecen a un período temprano, predomina el tono desilusionante y desilusionado. 
El poeta, buscándose a sí mismo en un mundo que en Vigilias es por la mayor parte nocturno y lúgubre está confrontado, a catusa de su temperamento, a problemas enigmáticos que le hacen volcarse dentro de sí mismo y, a la vez, le empujan a buscar la explicación y la justificación de su existencia. Las preguntas dirigidas al mar en "Mar por la tarde":

“¿ Dónde principias, mar, dónde te viertes?

¿qué mares invisibles, mar, alias?"

llevan al poeta a su propia situación:

"¿Dónde principias, tiempo, vida mía",

y sugieren que no hay explicación lógica para la existencia humana, hasta el punto que el ser humano, consciente de su soledad, en su búsque$\mathrm{da}$ interior y exterior ve en Dios al adversario. Dice el poeta en "Otoño":

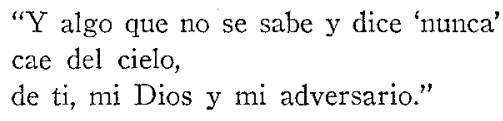

No halla tampoco el consuelo del sueño; está dominado el grupo Vigilias por el insomnio, el tedio, por la completa falta de relaciones humanas y la amarga conciencia de las limitaciones de la vida humana:

"El nacer y el morir son las fronteras",

La interpretación artística del estado atormentado del alma está hecha por medio de metáforas que en su conjunto de realismo y fantasía recuerdan la metáfora sorprendente del conceptismo: habla el poeta del aire asesinado y de los vocablos buérfanos en "Nocturno", y en "Lágrima" dice:

\footnotetext{
"Su rastro es piedra calcinada, salitre bajo el sol."
}

No hay sentimentalismo. La indiferencia del mundo, duro como las piedras y murallas en los versos dirigidos a Rafael Vega Albela, "Crepúsculo de la ciudad", está expuesta concisamente. Aquí ve el poeta nada más que lo lúgubre y hostil: calles sin fin andadas, desvario sin fin del pensamiento desvelado, destrucción y tedio bajo un cielo totalmente indiferente 
e impermeable, con la sola certidumbre de la nada. En Mar por la tarde el poeta ve analogía entre lo que observa en el mundo exterior y su propio estado de alma hasta el extremo que identifica el mar, que naufraga en sí mismo, con su experiencia, haciendo así de la última estrofa una metáfora de la nulidad de la vida humana:

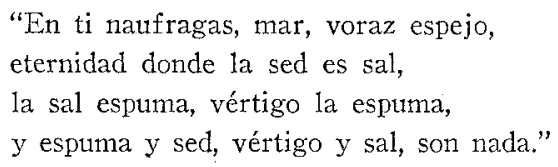

Es un alivio parcial cuando en "Envío", último poema de Vigilias, el autor se aparta algo de la completa desolación, sintiendo que la palabra le llega no para dirigirse a alguien sino para darle la realizción de su personalidad:

$$
\text { "y se rescata, y vuelve a ser yo mismo." }
$$

No es la metáfora el único medio de Octavio Paz para comunicar sus angustias y preocupaciones. El poeta usa a veces la repetición, especialmente la repetición intensa de preguntas directas, por ejemplo, ¿cómo decir? en "Nocturno" y ¿dónde pricipias, mar?, ¿dónde principias, tiempo? en "Mar por la tarde". También emplea, en contraste con el lenguaje simbólico, palabras sencillisimas, como en "Pregunta":

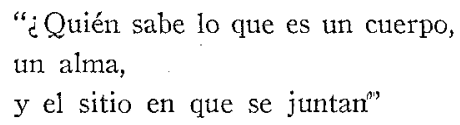

y repetición con el juego musical de palabras como en "El espejo" cuando dice:

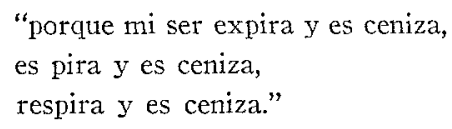

En suma, el tono de Vigilias indica conciencia de inteligencia y razón:

"Y nada queda, sino el goce impío de la razón, cayendo en la inefable y helada intimidad de su vacío", 
pero completa incapacidad de aceptar la validez de un mundo espiritual fuera de la experiencia individual y personal. Así lo único que queda en las exploraciones del mundo metafísico es la nada, hacia la cual el poeta se siente inexorablemente destinado.

Nos parece oportuno seguir con la discusión de los otros grupos cronológicamente, puesto que se entrelazan en sus fechas. Después del negativismo de Vigilias, poemas de fecha posterior contrastan con las experiencias lúgubres del insomnio; así los versos de Asueto son, en parte, versos de luz y de resplandor. No se trata de una descripción tradicional de la naturaleza; más bien de una creación que resulta de dos corrientes recíprocas, una saliendo de las impresiones del mundo exterior, otra la que brota dentro del poeta y evoca para él una riqueza de asociaciones mientras observa el verano campestre del paisaje mexicano. Así hay un conjunto de la realidad del verano y su exuberancia, lluvias, sol, la naturaleza despierta y la experiencia personalísima que es conciencia de la plenitud de la vida interior, a veces una plenitud casi falsa, desilusionante, una "mentida plenitud" en "Junio", a veces conciencia de verdadera riqueza interior "la plenitud silenciosa de lo vivo", en "Medianoche". No hay énfasis en lo regional: el ambiente local es experimentado en primer lugar como ambiente en el cual el poeta se analiza a sí mismo. Proyecta el resplandor del verano sobre el alma del poeta una cantidad de matices sorprendentes, pero no goza en el sentido convencional de la vida deleitosa, tranquila, buscada por muchos en la serenidad del campo; más bien se da cuenta agudamente de un torbellino de sensaciones interiores dentro de su propio temperamento que está como para estallar al encararse con la realidad. El frecuente uso de la primera persona podría invitar al error de ver en la poesía de Octavio Paz puramente un análisis subjetivo del artista. En su caso puede decirse que palabras nacidas de experiencias personalísimas se convierten en palabras de sentido universal. El mundo exterior que le inspira las metáforas e imágenes es el de los ríos, lagos y montañas de México, pero en sus calidades intrínsecas no hay rastro de provincialismo, como tampoco lo hay en poemas de situación metropolitana: En el poema "En la calzada" dice:

"Todos caminan, nadie se detiene. Cada uno a su pequeño negocio." 
Y si el ambiente, en unos casos, tiene algo de las misteriosas noches de Rufino Tamayo, la pesadilla nocturna es también experiencia universal. La realidad del paisaje tiene varios efectos: no causa impresiones que son estáticas, sino estando la disposición del poeta sujeta a influencias sutilísimas, el tono fluctúa entre el pesimismo y la desilusión, de un lado, y susceptibilidad para lo hermoso, de otro lado, facilitando así el aprecio de la "plenitud silenciosa de lo vivo".

En algunos poemas de Asueto se muestra Octavio Paz también maestro del verso dentro de la tradición de la teoría poética "la musique avant toute chose": musicalidad, movimiento, ritmo, ligereza, caracterizan las poesías "Viento", "Espiral", "Nubes", sin que estos poemas sean poesía solamente descriptiva. Siempre es el hombre el que vive, absorbe y refleja la naturaleza.

El intercambio entre los dos mundos, el interior y el exterior, parece ser la base de la experiencia poética de Octavio Paz, cuando contempla el paisaje en sus varios aspectos. Típico de este intercambio es el poema "Lago": las imágenes se refieren a lo visto, como las aguas prisioneras, el resplandor indolente, el cielo caído e insinúan que tal observación del mundo exterior sólo es posible para uno que vive con toda la sensibili$\mathrm{dad}$ al interior y para quien las impresiones sensoriales causan, por una serie de asociaciones, una evocación repentina de la experiencia interior:

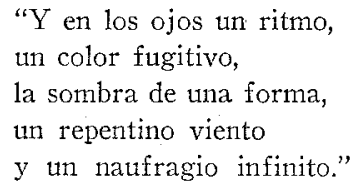

En los poemas de amor (Girasol) la conciencia de la fugacidad del tiempo se hace aguda. Preocupaciones latentes, el sondear de los límites de la existencia humana ante la abundancia vital de la belleza, el entregarse a toda la gama de los placeres sensuales causan que la vida humana se convierta en "una pausa entre este tiempo y otro sin medida", pero una pausa no de angustia, ni de soledad desesperada, sino de mayor goce y de sutilisima impresionabilidad. En "Cuerpo a la vista" esta entrega a la experiencia amorosa es expresada por imágenes de resplandor y exuberancia:

\footnotetext{
"tu pelo, silencioso río solar, otoño espeso, caída de agua de hojas doradas",
} 
"tu piel pan apenas dorado y tus ojos de azúcar quemado".

Las últimas líneas de este poema, destacándose por su distinta forma métrica como un envío insinúan la posibilidad de un vencimiento de la angustia y la aceptación del confín restringido de la vida humana:

"Patria de sangre,

única tierra que conozco y me conoce, única patria en la que creo

única puerta al infinito."

Comparando los dos Noctumos -el de Girasol y el de Vigiliasla vacilación e inquietud acentuada por la repetida pregunta "cómo decir", se han convertido en aceptación de los misterios de la vida. En ambos Noctumos la noche no sugiere fuga de la realidad, en el sentido tradicionalmente romántico, sino que sutiliza la facultad de percepción; el silencio y la soledad todavía predominan, pero ya no oprimen:

"un río, una corriente dulce y silenciosa, te inunda por dentro, avanza, te hace oscura:

la noche moja riberas en tu alma."

Si los grupos de poemas Vigilias, Asueto y El girasol son de cierto modo restringidos por el ambiente escogido por el autor y por su estado de ánimo en nun número de circunstancias, "Puerta condenada" es ya más expresión de una ideología alcanzada en un momento decisivo, no sólo por el poeta, sino por el filósofo Octavio Paz. En "Puerta condenada", después de pasar por un mundo lleno y abierto, se encuentra en la situación en la cual recuerda una vida de abundancia, de erotismo, de busca, pero la creación artística de lo vivido tampoco da calma ni satisfacción. Está el maro que cierra el paso, parece inalcanzable la plena serenidad. La futilidad de la existencia y la falta de estar anclado por vínculos a algo que dure, son las mayores desilusiones. Dice el poeta en "Razones para morir":

"No hay patria, hay tierra, imágenes de tierra, polvo y luz en el tiempo..."

"Otros me hablan de la gloria.

¿Durar? ¿Dura la flor? Su llama fresca

en la mano del viento se deshoja:

la flor quiere bailar, sólo bailar." 
Los recuerdos e impresiones de una vida dejan sus huellas sin ser de importancia cabal. El esfuerzo de librarse de este mundo tangible es procedimiento difícil, puesto que cada detalle adquiere valores emocionales. La necesidad de abandonar la familiaridad de un ambiente en la instabilidad de la vida es inexorable como en "Adiós a la casa":

"Quiero decir adiós a este pequeño mundo, único mundo verdadero."

Prevalece el tono de soledad en "El visitante", "La calle" y en "Elegía interrumpida". En "Cuarto de hotel", poema que por el mismo título evoca la impersonalidad de un ambiente triste y vacio, el poeta llega otra vez a conclusiones amargas en cuestiones de fe:

"No nos espera Dios al fin de la semana.

Duerme, no lo despiertan nuestros gritos",

"y al reino de su nada volveremos."

Pero no es ésta la actitud final del poeta. Aunque sigue sintiendo hondamente la soledad y la falta de estabilidad y aunque sigue solo dentro del silencio y bullicio, habla ahora en un tono reconciliador. E1 buscarse a sí mismo por la relación con el mundo, el hallar la significación de la personalidad integrándose dentro de la sociedad humana hacen posible para el poeta la aceptación de lo que es substancial y sencillo, del vivir con máxima intensidad dentro de los límites humanos, del llegar a la muerte con serenidad, como lo dice en la vida sencilla:

\footnotetext{
"Llamar al pan el pan y que aparezca sobre el mantel el pan de cada día";

"darle al sudor lo suyo y darle al sueño y al breve paraíso y al infierno y al cuerpo y al minuto lo que piden"; "Y que a la hora de mi muerte logre morir como los hombres y me alcance el perdón..."
}

Alcanza en "Himno entre ruinas" un triunfo definitivo sobre la fugacidad del tiempo y la soledad del individuo. Sobre el fondo grandioso de las ruinas de Teotihuacán, símbolo de lo transitorio de toda cultura humana, el poeta ve una reconciliación de la inteligencia con la concienciaespejo: consciente de las dos fuerzas dentro de sí, el hombre ya no es 
arrastrado por la una o la otra, sino que ve su misión y su dignidad en sus actos:

\author{
"La inteligencia al fin encarna en formas, \\ se reconcilian las dos mitades enemigas \\ y la conciencia-espejo se licúa, \\ vuelve a ser fuente, manantial de fábulas: \\ Hombre, árbol de imágenes, \\ palabras que son flores, que son frutos, que son actos."
}

Gabriele von Munk Benton

\title{
Luis Monguió, La poesía postmodernista pernana.-University of Cali- fornia Press, 1954.
}

En 1952 Luis Monguió publicó, por intermedio del Hispanic Institute de New York, una importante monografía - la más completa que conocemos - sobre César Vallejo. El libro que ahora comentamos es una ampliación e intensificación de aquella búsqueda de materiales hecha en torno a la figura y el ambiente cultural del gran poeta peruano. Becado por la John Simon Guggenheim Memorial Foundation de New York durante el año lectivo de 1951-1952, Luis Monguió pudo revisar pacientemente el fondo bibliográfico del Instituto Hispánico de la Universidad de Columbia, de la Biblioteca del Congreso de los Estados Unidos, de la Biblioteca de la Universidad de California, en Berkeley y de la Biblioteca Nacional del Perú. Luego de examinar una por una la obra de los autores tratados, de organizar y estudiar la crítica existente sobre cada uno de ellos, de ver y rever revistas, periódicos y diarios de la época estudiada, el distinguido profesor del Mills College nos da una obra exhaustiva sobre el período de la poesía peruana que va desde las últimas décadas del siglo pasado hasta los poetas más recientes, como Martín Adam, Gustavo Valcárcel o Salazar Bondy. Trabajo de un investigador responsable y seguro, es, además, el de un fino espíritu de artista que, a la par que ordena y medita, discierne y juzga, siente, goza y hace gustar los verdaderos valores de la poesía. Cabe destacarlo, porque la investigación literaria ha dejado de ser un mero acopio erudito de ficheros técnicamente clasificados; hoy sabemos que la investigación es todo eso, sin lo cual no habría investigación, pero sabemos también que es algo más: el hallazgo de un mundo de vida 